\title{
Feromone van die denneboom-pou-oogmot
}

\author{
Outeurs: \\ Luki-Marié Scheepers, ${ }^{\text {a,b }}$ \\ B Slippers, \\ MC Bouwer, a,b \\ ER Rohwer ${ }^{a}$ \\ Affiliasies: \\ apepartement Chemie, \\ Universiteit van Pretoria \\ Privaatsak X20, Hatfield, \\ 0028 \\ 'Instituut vir Bosbou- en \\ Landboutegnologie, \\ Universiteit van Pretoria \\ Korresponderende outeur: \\ Luki-Marié Scheepers \\ E-pos: \\ lukimarie.scheepers@gmail.com \\ Hoe om hierdie artikel aan \\ te haal: \\ Luki-Marié Scheepers, \\ B Slippers, MC Bouwer \\ ER Rohwer, Feromone \\ van die denneboom- \\ pou-oogmot, Suid- \\ Afrikaanse Tydskrif vir \\ Natuurwetenskap en \\ Tegnologie 38(1) (2019). \\ https://doi.org/10.36303/ \\ SATNT.2019.38.1.783 \\ Kopiereg: \\ (C) 2019. Authors. \\ Licensee: Die Suid- \\ Afrikaanse Akademie vir \\ Wetenskap en Kuns. \\ Hierdie werk is onder \\ die Creative Commons \\ Attribution License \\ gelisensieer
}

Pheromones of the pine tree emperor moth: This study represents the first evidence of a possible second component in the pheromone of the pine tree emperor moth after GCEAD studies have shown two repeatable antennal responses to female extracts. Preliminary screenings of mitochondrial cytochrome oxidase I gene regions also confirmed that a single sub-species of this moth is found in KwaZulu-Natal and Mpumalanga.

Insekte kommunikeer met afskeidings in die gasfase. Chemiese stowwe word deur 'n individuele insek geproduseer en in die omgewing afgeskei, en reseptore op die ontvanger se antennas neem die sein waar. Die gevolglike fisiologiese reaksie kan òf aantrekkend òf afstotend wees. Feromone kan gedefinieer word as stowwe wat ander lede van dieselfde spesie aantrek en 'n gedragsreaksie of verandering by die ontvanger veroorsaak. Natuurlike feromoonkommunikasie tussen insekpeste word oor die algemeen aangewend vir gebruik in massalokvalle, paringversteuring asook die monitering van populasiegetalle in pesbeheer. Die ekologie en gedragsgewoontes moet egter eers verstaan word om te weet waar in die insek die feromoon geproduseer word, asook wanneer die feromoon geproduseer word en deur watter tipe lid van die spesie.

Vorige navorsing oor die denneboom-pou-oogmot, Nudaurelia cytherea (Fabricius 1775) (Lepidoptera: Saturniidae), het aangedui dat vroulike motte die feromoon in hulle posterior abdominale segment produseer. Die feromoon lok manlike motte, wie se antennas hipersensitief vir olfaktoriese kommunikasie is. Ander motte in dieselfde motfamilie (Saturniidae), insluitend Bombyx mori, se ekologie, gedrag en feromoonkommunikasie is omvattend beskryf en word beskou as soortgelyk aan die denneboom-pou-oogmot. Die denneboom-pou-oogmot se feromoon is voorheen geïsoleer, beskryf en in feromoon-lokvalle getoets. Dié lokvalle was egter nie spesie-spesifiek nie. Hierdie endemiese mot berokken jaarliks skade in denneplantasies as gevolg van sporadiese populasie-ontploffings, wat afhanklik is van baie omgewingsfaktore. Die doel van hierdie studie was om te bepaal of die feromoonsamestelling volledig beskryf is en of ander komponente ontbreek in vorige feromoonbeskrywende literatuur in die 1970's. Daar is twee Suid-Afrikaanse spesies wat voorheen beskryf is as subspesies van Nudauleria cytherea, naamlik N. cytherea cytherea en N. cytherea clarki. Die spesies staan nou bekend as $N$. cytherea en N. clarki, maar bewyse van die verwantskap tussen die spesies ontbreek. Die spesies vreet onderskeidelik aan Pinus radiata (D Don) en Pinus patula (Schlecht. \& Cham.). Die feromoonkommunikasie van selfs naverwante subspesies mag verskil. 'n Volgende doelstelling was dus om vas te stel of die motte wat vir die studie gebruik is van dieselfde spesie is en of hulle verskillende spesies verteenwoordig.

Heksaanekstrakte van die vroulike posteriorsegment is in komponente geskei deur middel van gaschromatografie (GC). Antennadepolarisasie-metingsinstrumente (EAD) is gebruik om neurologiese response van die antennas van manlike denneboom-pou-oogmotte ten opsigte van die gasagtige stowwe te bepaal. GC-MS- (gaschromatografie-massaspektrometrie) metodes is gebruik vir voorlopige struktuurbepalings en bevestigingstudies met die gesintetiseerde feromoonkomponent, cis-dek-5-eniel-3-metielbutanoaat, wat voorheen beskryf is. Hierdie studie bied die eerste bewyse dat die feromoon van die denneboom-pou-oogmot nie net een komponent bevat nie, maar twee. Vergelykings tussen die ekstrak en gesintetiseerde feromoon het bewys dat die struktuur van die onbekende feromoonkomponent nou verwant is aan die gepubliseerde struktuur. DNA-ekstraksies van die motbene is uitgevoer. Die voorlopige sitochroomoksidase-I mitochondriale geenbepalings is met dieselfde geen van ander Saturniidae-motte vergelyk. Die geenbepalings het bevestig dat slegs een denneboompou-oogmot subspesie in KwaZulu-Natal en Mpumalanga teenwoordig is, aangesien daar nie variasie in die COI-geen gevind is nie.

Nota: 'n Seleksie van referaatopsommings: Studentesimposium in die Natuurwetenskappe, 25-26 Oktober 2018, SA Akademiegebou, Pretoria, Suid-Afrika. Gasredakteurs: Prof Rudi Pretorius (Departement Geografie, Universiteit van Suid-Afrika); Prof Chris Swanepoel (Departement Besluitkunde, Universiteit van Suid-Afrika); Me Andrea Lombard (Departement Geografie, Universiteit van Suid-Afrika) 